\title{
Analisis Akuntansi Pertanggungjawaban dalam Penentuan Anggaran Biaya Pemasaran
}

\author{
Tetep \\ Ade Suherman \\ Fakultas Pendidikan Ilmu Sosial Bahasa dan Sastra, Institut Pendidikan Indonesia Garut \\ Jalan Terusan Pahlawan no. 32 Tarogong Garut \\ tetep@institutpendidikan.ac.id
}

\begin{abstract}
Abstrak-Setiap perusahaan harus menentukan penentuan anggaran pemasaran yang tepat agar pemasaran berjalan dengan baik. Perusahaan harus menerapkan manajemen pemasaran yang baik, memilih strategi pemasaran yang tepat, mampu memilih pasar yang sesuai dan menentukan anggaran biaya pemasaran yang sesuai. Untuk itu perlu melaksanakan sistem akuntansi manajemen yang baik dengan membuat sistem informasi akuntansi pertanggungjawaban (activity-based responsibility accounting system), melalui pusatpusat pertanggungjawaban. Ada beberapa hal yang menjadi permasalahan yang terdapat di PT. Pos dan Giro Ciamis yaitu; 1) Anggaran yang dilakukan relatif masih rendah. Hal ini terlihat dari kegiatan yang akan dilaksanakan pada perusahaan tidak mencakup berbagai kegiatan yang saling berkaitan dan saling mempengaruhi satu sama lainnya. 2) Penerapan informasi akuntansi pertanggungjawaban pada PT. Pos dan Giro Ciamis belum cukup memadai. Hal ini terlihat bahwa perusahaan belum menerapkan sistem akuntansi pertanggungjawaban diantaranya struktur organisasi, penyusunan dan penentuan anggaran; pemisahan biaya terkendali dan tidak terkendali; dan sistem pelaporan biaya. Hasil penelitian dapat disimpulkan sebagai berikut: 1) Penerapan akuntansi pertanggungjawaban di Kantor Pos Ciamissudah sangat efektif. Hal ini dapat dilihat dari struktur organisasi, penggolongan biaya, sistem pelaporan dan penyusunan anggaran. Strutur organisasi pada perusahaan ini telah menunjukan adanya pendelegasian tugas. Wewenang dan tanggungjawab pada setiap unit organisasi dan telah terlihat adanya uraian tugas dan tanggungjawab dari masing-masing pusat pertangungjawaban. 2) Penetuan anggaran baiya pemasaran di Kantor Pos Ciamissudah cukup baik. Hal ini tercermin dengan perencanaan mengenai perincian biaya, adanya alokasi, pengendalian dan prosedur dari anggota biaya oemasaran. 3) Pelaksanaan akuntansi pertanggungjawaban yang ditempatkan oleh Kantor Pos Ciamis berimplikasi terhadap penentuan anggaran biaya pemasaran di Kantor Pos Ciamis.
\end{abstract}

Kata Kunci- Anslisis Akuntansi, Biaya Pemasaran, Pertanggungjawaban

\section{PENDAHULUAN}

Perusahaan dalam mengelola suatu usahanya, manajemen dituntut untuk mengendalikan semua aktivitas operasionalnya. Pada sistem manajemen modern fungsi perencanaan dan pengendalian merupakan hal yang penting sebagai inti dari fungsi manajemen. Fungsi perencanaan berhubungan dengan proses berpikir dalam mengambil keputusan atau langkah-langkah tentang cara bertindak setelah mempertimbangkan anternatif beberapa kemungkinan yang terjadi. Sedangkan fungsi pengendalian merupakan proses untuk menjamin bahwa perusahaan telah melaksanakan rencana secara efektif dan efisien. Begitu pula dalam proses pemasaran.

Setiap perusahaan harus menentukan penentuan anggaran pemasaran yang tepat agar pemasaran berjalan dengan baik. Perusahaan harus menerapkan manajemen pemasaran yang baik, memilih strategi pemasaran yang tepat, mampu memilih pasar yang sesuai dan menentukan anggaran biaya pemasaran yang sesuai. Untuk itu perlu melaksanakan sistem akuntansi manajemen yang baik dengan membuat sistem informasi akuntansi pertanggungjawaban (activity-based responsibility accounting system), melalui pusat-pusat pertanggungjawaban, seperti yang diutarakan oleh Mulyadi (2001:163) bahwa: "Akuntansi manajemen telah mengembangkan sistem akuntansi pertanggungjawaban berbasis aktivitas (activity based responsibility accounting system)". Sejalan dengan pendapat tersebut, menurut Horngren, Datar dan Foster (2006:231) bahwa : 
Akuntansi pertanggungjawaban adalah proses mengukur rencana, anggaran tindakan dan hasil actual dari setiap pusat pertanggungjawaban. Pusat pertanggungjawaban (responsibility center) adalah bagian, segmen, atau sub unit, dari organisasi dan manajernya bertanggungjawab atas segenap aktivitas tertentu, ada empat pusat pertanggungjawaban, yaitu: pusat biaya, pusat pendapatan, pusat laba dan pusat investasi.

Berdasakan pendapat di atas, dalam menentukan anggaran pemasaran perlu perlakuan akuntansi manajemen dengan membuat sistem informasi akuntansi pertanggungjawaban (activitybased responsibility accounting system), melalui pusat-pusat pertanggungjawaban agar kebutuhan, keinginan dan pilihan para pelanggan dari pusat biaya, pusat pendapatan, pusat laba serta pusat investasi mampu dioptimalkan dengan baik. Berasarkan hasil penjajagan di PT. Pos dan Giro Ciamis tahun 2018 bahwa yang menjadi permasalahannya sebagai berikut:

1. Anggaran yang dilakukan relatif masih rendah.

Hal ini terlihat dari kegiatan yang akan dilaksanakan pada perusahaan tidak mencakup berbagai kegiatan yang saling berkaitan dan saling mempengaruhi satu sama lainnya

2. Penerapan informasi akuntansi pertanggungjawaban pada PT. Pos dan Giro Ciamis belum cukup memadai. Hal ini terlihat bahwa perusahaan belum menerapkan sistem akuntansi pertanggungjawaban diantaranya struktur organisasi, penyusunan dan penentuan anggaran; pemisahan biaya terkendali dan tidak terkendali; dan sistem pelaporan biaya.

Pada kenyataannya masih banyak perusahaan yang belum sepenuhnya menerapkan akuntansi pertanggungjawaban sesuai dengan standar baku yang ditetapkan, dan masih banyak perusahaan yang belum sepenuhnya menerapkan anggaran biaya pemasaran sesuai dengan standar baku yang ditetapkan serta akuntansi pertanggungjawaban belum sepenuhnya diterapkan dalam menyusun anggaran biaya pemasaran.

\section{METODE}

Metode yang digunakan untuk meneliti masalah yang telah dikemukakan di atas, penulis menggunakan metode deskriptif analisis, yaitu dengan menggambarkan, menjelaskan, dan membuat kesimpulan tentang hasil penelitian PT. Pos Indonesia (Persero) Ciamis.
Winarno (2004:139) mengemukakan bahwa "Metode deskriptif adalah menuturkan dan menafsirkan data yang ada misalnya tentang situasi yang nampak dan sebagainya. Metode penelitain deskriptif ini adalah kegiatan penyelidikan data, menyusun dan mengklasifikasikan, menganalisi dan menginterpretasikan".

Selanjutnya menurut Moch. Nasir (2003:54) berpendapat bahwa:

Deskriptif analisis adalah suatu metode yang meneliti status kelompok manusia suatu objek, suatu set kondisi, suatu sistem pemikiran ataupun suatu kelas peristiwa pada masa sekarang yang bertujuan untuk membuat deskripsi, gambaran atau lukisan secara sistematis, faktual dan akurat mengani fakta-fakta, sifat-sifat serta hubungan antar fenomena yang terjadi.

Berdasarkan beberapa pendapat di atas dapat dijelaskan bahwa metode deskriptif analisis merupakan metode penelitian yang menggambarkan atau melukiskan secara sistematis, faktual dan akurat mengenai fakta-fakta dengan cara menyusun, mengklasifikasikan, menganalisa, dan menginterprestasikan sifat serta hubungan antar fenomena yang terjadi.

\section{HASIL DAN PEMBAHASAN}

Analiais Akuntansi Pertanggung jawaban pada PT. Pos Indonesia (Persero) Ciamis

Berdasarkan hasil analisis akuntansi pertanggung jawaban pada Kantor Pos Ciamis secara umum sudah cukup memadai dan berjalan secara efektif. Munculnya tanggung jawab merupakan akibat dari pelimpahan wewenang, dimana orang yang menerima wewenang mempunyai suatu kewajiban untuk melaksanakan serangkaian tindakan, sesuai dengan batas wewenang yang diberikan, kemudian mempertanggung jawaban kepada atasan yang memberikan wewenang tersebut. Pelimpahan wewenang yang ada di Kantor Pos Ciamis sematamata tidak terlepas dari syarat-syarat pertanggung jawaban yang harus di penuhi sebuah organisasi seperti : struktur organisasi, penyusunan anggaran, penggolongan biaya dan setiap kegiatan di Kantor Pos Ciamis tidak menyimpang dari apa yang telah ditargetkan dan menekankan pada cara penyajian laporan. Dengan demikian bila dilihat dari uraian diatas, kantor Pos Ciamis telah melakuakn akuntansi pertanggung jawaban sudah cukup memadai karena telah mengikuti prose yang cukup baik.

Penentuan Anggaran Biaya Pemasaran di PT. Pos Indonesia (Persero) Ciamis 
Penentuan anggaran baiaya pemasaran di Kantor Pos Ciamis sudah cukup baik. Hal ini terlihat dengan dilakukannya penyusunan anggaran biaya yang lebih terperinci untuk setiap tingkatan manajeman yang membebani tanggung jawab tersebut, pengalokasian biaya yang efektif dan dilakukannya penegndalian atau biaya-biaya yang terjadi dibagian pemasaran oleh manajer puncak. Hal tersebut sesuai dengan pengertian anggaran biaya pemasaran yang dikemukakan oleh Munandar (2001:187) adalah sebagai berikut :

Anggaran biaya pemasaran yaitu anggaran ayng merencanakan secara lebih terperinci tentang biaya-biaya yang terjadi serta terdapat dalam lingkungan bagian pemasaran, serta biaya-baiay lain yang berhubungan dengan kegiatan-kegiatan yang dilakukan oleh bagian pemasaran, yang didalamnya meliputi rencana tentang jenis biaya pemasaran, jumlah biaya pemasaran dan waktu (kapan) biaya pemasaran tersebut terjadi dibebankan, yang masing-masing dikaitak dengan tempat (departemen) dimana biaya pemasaran tersebut terjadi.

Selanjutnya menurut Mulyadi (2000:499) dalam penyusunan anggaran memerlukan berbagai tahapan berikut ini :

1. Penetapan sasaran oleh manajer atas

2. Pengajuan usulan aktivitas dan taksiran sumber daya yang diperlukan untuk melaksanakan aktivitas tersebut oleh manajer tingkat bawah.

3. Review oleh manajer terhadap usulan anggaran yang diajukan oleh manajer bawah

4. Persetujuan oleh manajer atas terhadap usulan anggaran yang diajukan oleh manajer bawah.

Penentuan anggaran biaya pemasaran harus memahami cara-cara atau langkah-langkah dalam melakukan perincian, pengalokasian dan pengendalian dalam penyusunan biaya pemasaran. Bila biaya-biaya tidak disusun dan dialokasikan dengan baik, maka tidak menutup kemungkinan adnya penyimpanganpenyimpangan yang terjadi. Maka agar hal tersebut tidak terjadi, baiya yang ada di bagian pemasaran harus dirinci dan dialokasikan seefektif mungkin serta harus adanya pengendalian dari manajer atas agar tidak ada penyimpangan.

Analisis Akuntansi Pertanggungjawaban Implikasinya Terhadap Penentuan Anggaran Biaya Pemasarasn Pada PT. Pos Indonesia (Persero) Ciamis

Berdasarkan hasil analisis akuntansi pertanggungjawaban pada Kantor Pos Ciamis sudah dapat dikatakan cukup memadai dan cukup efektif dan implikasinya terhadap anggaran biaya pemasara. Penentuan anggaran biaya pemasaran pada Kantor Pos Ciamis dapat dikendalikan dengan baik dan jauh dari penyimpangan-penyimpangan. Hal ini dikarenakan Kantor Pos Ciamis telah menerapkan akuntansi pertanggungjawaban dengan cukup baik dengan memenuhi syarat-syarat yang telah ditentukan.

Hal ini sesuai dengan pendapat Munandar (2001:187) yang mengemukakan bahwa:

Anggaran biaya pemasaran yaitu anggaran yang merencanakan secara lebih terperinci tentang biaya-biaya yang terjadi serta terdapat dalam lingkungan bagian pemasaran serta biaya-biaya lain yang berhubungan dengan kegiata-kegiatan yang dilakukan oleh kegiatan pemasaran, yang didalamnya meliputi rencana-rencana tentang jenis biaya pemasaran, jumlah baiay pemasaran, jumlah dan waktu (kapan) biaya pemasaran terjadi dan dibebankan yang masing-masing dikaitakan dengan tempat (departemen) dimana biaya pemasaran tersebut terjadi.

Dengan dijalankannya akuntansi pertanggungjawaban maka biaya atau pendapatan dapat dianggarkan dengan baik. Terutama bagian pemasaran, dibagian inidibutuhkan akuntasi pertanggungjawaban sebagai jalannya alur produksi tergantung pada tingkat pemasaran. Dimana dalam anggaran biaya pemasaran secara terperinci semua biaya dari mulai proses produksi sampai ketangan konsumen dianggarkan.

\section{SIMPULAN}

Berdasarkan pembahasan hasil penelitian yang didukung teori-teori yang dipelajari dan hasil pembahasan pada bab sebelumnya, maka dapat disimpulkan sebagai berikut :

1. Penerapan akuntansi pertanggungjawaban di Kantor Pos Ciamis sudah sangat efektif. Hal ini dapat dilihat dari struktur organisasi, penggolongan biaya, sistem pelaporan dan penyusunan anggaran. Strutur organisasi pada perusahaan ini telah menunjukan adanya pendelegasian tugas. Wewenang dan tanggungjawab pada setiap unit organisasi dan telah terlihat adanya uraian tugas dan tanggungjawab dari masing-masing pusat pertangungjawaban. 
2. Penetuan anggaran baiya pemasaran di Kantor Pos Ciamis sudah cukup baik. Hal ini tercermin dengan perencanaan mengenai perincian biaya, adanya alokasi, pengendalian dan prosedur dari anggota biaya pemasaran.

3. Pelaksanaan akuntansi pertanggungjawaban yang ditempatkan oleh Kantor Pos Ciamis berimplikasi terhadap penentuan anggaran biaya pemasaran di Kantor Pos Ciamis.

\section{REFERENSI}

[1] Djaslim Saladin dan Herry Achmad Buchory, 2010, Manajemen Pemasaran, Cetakan Pertama, Bandung, CV Linda Karya.

[2] Horngren, Datar dan Foster (2006. Ost Accounting:a Managerial Emphasis. 12th Edition. Pearson Prentice Hall. New Jersey.

[3] Kotler, Philip dan Amstrong, 2002, Manajemen Pemasaran. Edisi Milenium, PT Perhalindo:Jakarta

[4] Moh Nazir, 2003. Metode Penelitian. Jakarta: Ghalia Indonesia 2003

[5] Mowen 2005. Management Accounting Buku 2 Edisi ke 7. Jakarta:Salemba Empat

[6] Mulyadi. 2001. Sistem Akuntansi. Jakarta: Salemba Empat.

a. . 2005. Akuntansi Biaya. Jakarta: Salemba Empat.

[7] Saladin, Djaslim. 2003. Intisari Pemasaran dan Unsur-Unsur Pemasaran. Cetakan Ketiga, Bandung:Lindakarya.

[8] Simamora, H. 2001. Akuntansi Manjemen. Salemba Empat. Jakarta.

[9] Supriyono, 2001. Akuntansi Manajemen I Konsep Dasar Akuntansi Manajemen dan Proses Perencanaan, BPFE, Yogyakarta.

[10] Winarno Surakhmad, 2004. Pengantar Penelitian Ilmiah Dasar Metode dan Teknik, Tarsito, Bandung. 